\title{
Changing the Groundwater Landscape of India: Implications to Drinking Water, Food Security, Socio-Economy and Public Health
}

\author{
ABHIJIT MUKHERJEE ${ }^{1, *}$ \\ ${ }^{1}$ Applied Policy Advisory for Hydrogeoscience (APAH) Group, Department of Geology and Geophysics \\ and School of Environmental Science and Engineering, Indian Institute of Technology (IIT)-Kharagpur, \\ India
}

(Received on 22 February 2019; Revised on 26 August 2019; Accepted on 31 August 2019)

\begin{abstract}
Delineating the changing scenarios of groundwater in a developing country like India is intricately dependent on understanding the intrinsic and dynamic interplay between natural processes, human practices and policy interventions. Huge groundwaterdependent population, uncertain climate-resilient recharge processes, transboundary upstream surface water sources, major geogenic-sourced non-point contaminants, archaic irrigation methods and human practices, and indiscriminate land use changes, along with the urbanization and prolific use of anthropogenic point-sourced pollutants, have rendered the Indian groundwater scenario to become a global paradigm for water scarcity and insecurity, from the perspective of both quantity and quality. Impending climate change is expected to aggravate this situation further.
\end{abstract}

\begin{abstract}
While, the country hosts some of the richest fluvial aquifers of the world, abstraction of the "largest groundwater volume in human history" have led to "groundwater drought", caused by overdraft across major parts of India. Thus, the huge groundwater abstraction, mostly used for food production, has significantly impacted the socio-economy. India has been identified as one of the largest exporter of non-renewable groundwater through international food trade. Further, conducive, geogenic sources and processes, result into pervasive, natural groundwater contaminants (e.g. As, F etc.) across the country, thus posing severe health risks for millions of Indians. Additionally, indiscriminate introduction of human-sourced emerging pollutants and improper sanitation practices leads to further quality deterioration.

Hence, a series of scientifically-prudent, adaptive groundwater management strategies are immediately required to secure, sustain and rejuvenate the accessible, residual, unpolluted groundwater through times of changing socio-economic needs. However, recent studies do show scenarios of replenishment, potentially caused by policy interventions. Thus, proper pervasive groundwater governance may optimistically lead to possibilities of transforming the country from a "groundwaterdeficient" to "ground-water sufficient" nation, and providing safe and sustainable water availability.
\end{abstract}

Keywords: Groundwater; Aquifer; Pollution; Society; Drinking Water; India

\section{Introduction}

Groundwater is the largest volume of available freshwater resource for humans across the globe, which plays a crucial role in providing drinking water and food security by supporting irrigated agriculture. Indian groundwater condition has become a global paradigm for water scarcity, in terms of both quantity and quality. While, the country hosts some of the richest fluvial aquifers of the world, abstraction of the "largest groundwater volume in human history" has led to "groundwater drought", caused by overdraft across major parts of India (Mukherjee et al., 2018a). It's groundwater abstraction is presently higher than the sum of the total groundwater abstraction of United States and China, the second and third highest groundwater user countries, respectively (Mukherjee et al., 2015; Mukherjee, 2018). India occupies only $\sim 2 \%$ of the global terrestrial land share, but hosts almost 1/5th $(\sim 19 \%)$ of the global population (FAO,

*Author for Correspondence: E-mail: amukh2@gmail.com 
2013). It also covers more than $30 \%$ of the global irrigated land. The country is witnessing a rapid rise in population, urbanization and change in anthropogenic water use, cropping pattern and lifestyle leading to unsustainable abstraction of available groundwater [e.g., 245 billion cubic meters (BCM) irrigational groundwater abstracted from India alone during 2011 only, which is at least $25 \%$ of the total global groundwater withdrawal]. These result to groundwater withdrawal to availability ratio being higher than 0.8 (i.e., more than $80 \%$ of the available groundwater has been withdrawn) in most parts of the country, and India is now identified as one of the largest exporter of non-renewable groundwater through international food trade (Bhanja et al., 2017; Dalin et al., 2017).

Large-scale use of groundwater for human consumption, domestic purposes and agricultural production has consequently exposed the population to issues related to water quantity (shortage or excess of groundwater resources), as well as water quality (lack of availability of potable and safe drinking water for human intake). The availability of groundwater resources are highly heterogeneous in the Indian subcontinent and significantly vary between different geological and geomorphological terrains. This skewed distribution of groundwater resources burdened by the enormous stress of sustaining a population of more than 1.3 billion has resulted in increasing water crisis, which has been an issue of prime concern for public health, socio-economy and politics in India (Mukherjee et al., 2015). Additionally, studies suggest that the recent changes in climatic patterns are hypothesized to intensify the problem. Verma and Phansalker (2007), it has been estimated that, in India, during each hydrological year, about 4000 billion $\mathrm{m}^{3}$ of water inflows into the hydrologic system. Of these, unaccounted loss of water in processes like outflow to oceans, evapotranspiration, and seepage to very deep levels or pipeline leakages makes up for $\sim 50 \%$ of the water budget. Out of the residual accounted water resource of 2000 billion cubic meters, $60 \%$ is housed in the great alluvial plains of the Indus-GangesBrahmaputra river systems in north India (Mukherjee et al., 2018), which aerially constitutes only $35 \%$ of the Indian subcontinental landmass. Thus, it implies that the remaining $65 \%$ of the areal landmass covering the western and southern regions of India receives only $40 \%$ of the total annual water budget of India, resulting is an extremely inequitable distribution of groundwater resource within the landmass (Mukherjee et al., 2015; Mukherjee, 2018) (Fig. 1).

Furthermore, in the four monsoonal months in India stretching from June to September, the north and south Indian rivers carries for $60 \%$ to $80 \%$ of the annual water flow, which results in skewed seasonal water budgets even in temporal scale. Although, the Indian groundwater scenario reveals that the most of the northern states of India have abundant water resource (Kumar et al., 2005), the availability of clean potable water is limited due to the indiscriminate use of rivers and other surface-water bodies as industrial wastes and sewage disposal outlets (Mukherjee et al., 2011), resulting in a large-scale shift to groundwater usage. On the other hand, groundwater in many parts of the country often contain toxic levels (above the World Health Organization's (WHO) permissible limit for drinking water) of naturally occurring, geogenic and non-point source contaminants e.g., arsenic (As), fluoride (F) which have exposed millions of people to severe health hazards (Mukherjee et al., 2015; Mukherjee, 2018). The extent and severity of arsenic pollution in the groundwater of lower Gangetic basin covering major parts of West Bengal (and neighboring areas of Bangladesh), Bihar and Uttar Pradesh is known to be the largest mass poisoning in human history. Recent discoveries (Mukherjee et al., 2011) showed presence of high arsenic groundwater in major portions of Brahmaputra basin in north-eastern India. Thus, delineating alternative, safe and sustainable sources of drinking water is of the highest priority in present time.

Prolonged issue of water scarcity would eventually result in food scarcity. Present rates of groundwater abstraction are significantly high compared to the reserve volume, making it unsustainable on a long term, especially in areas of north-west India (Rodell et al., 2009) and the Ganges basin (Tiwari et al., 2009; Bhanja et al., 2016, 2017; 2019; Mukehrjee et al., 2018), where groundwater levels are reported to be declining at an alarming rate. The total count of mechanized irrigational tube wells have steadily gone up from being 1 million in 1960's to about 19 million in 2000 (Deb Roy and Shah, 2003). Furthermore, extensive and unplanned groundwater abstraction has led to significant deterioration in the groundwater quality by processes such as, infiltration 


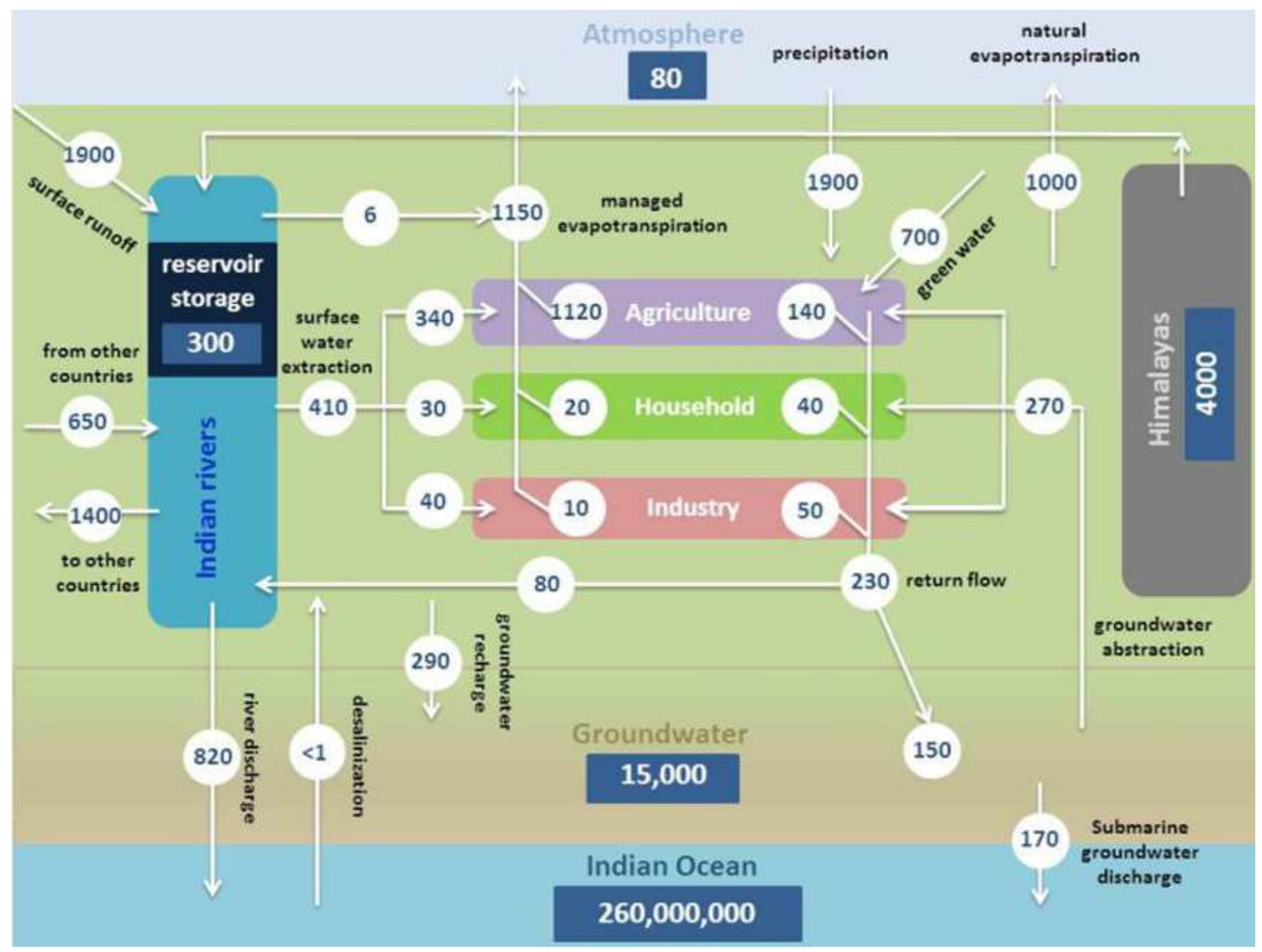

Fig. 1: Estimated water volumes residing in various surface and groundwater storage and processes (in present days). The numbers indicated in boxes (water storage) and circles (water flow/processes) are denoted in $\mathbf{~ m}^{3}$ and $\mathbf{~ k m}^{3} / \mathbf{y e a r}$ respectively. Drawn with the input from Mukherjee et al. (2015); MacDonald et al. (2016); Bhanja et al. (2017, 2019); IIT (2018); Bhanja and Mukherjee (2019) and references there in

of toxic contaminants like arsenic to the previously safe aquifers levels (Mukherjee et al., 2011; 2018).

\section{Groundwater Availability and Trends}

India has been using groundwater from historical time period by using traditional methods to construct wells and abstract water. As far as historical information is available, use of groundwater for domestic and irrigation purpose was known in the Indus Valley Civilization, where the city of Mahenjo-Daro had $>700$ wells, and are often called "The city of Wells" (Keynor, 1998). Usage of groundwater as drinking water is also well documented in the mythological battle of Kurukshetra in the ancient Indian epic of Mahabharata. There are ample further examples of such usage throughout the documented history of
South Asia, from the Mauryan era to the colonial period. However, it is only in the post-independence era (late-1960s to early 1970s), groundwater became a pivotal natural, societal and economic resource, where agriculture renaissance in form of the Green Revolution turned India from being food-deficient to food-sufficient (Mukherjee et al., 2015; Mukherjee, 2018). Groundwater use for enhanced crop production played a primary role in the rapid increase of groundwater abstraction through shallow tube wells and heavy-duty motorized pumps, in India after the 1960s. Thus, groundwater is now the predominant source of water for agriculture, industry and domestic purposes. In regions of high-quality abundant groundwater, dug-wells and tube wells have become reliable sources of perpetual water supply in ones 
Table 1: Time lines of evolution of water (specifically groundwater) usage in South Asia/India (Mukherjee et al., 2015; ITT, 2018; Mukherjee, 2018 and references there in)

\begin{tabular}{|c|c|c|c|c|}
\hline Remark & Age & Period & Time lines & Events \\
\hline \multirow{18}{*}{ 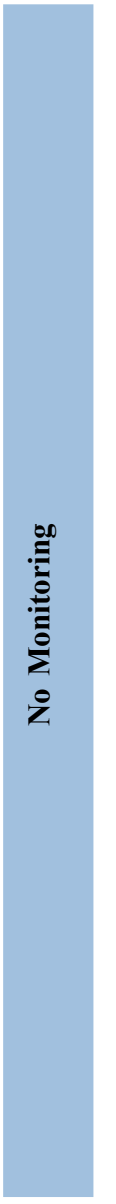 } & \multirow[t]{9}{*}{$\begin{array}{l}\text { 4500BCE } \\
\text { onwards }\end{array}$} & $\begin{array}{l}\text { Ancient } \\
\text { to }\end{array}$ & $4500 \mathrm{BCE}$ & Irrigation in Indus and Ganges basin \\
\hline & & \multirow[t]{8}{*}{ Medieval } & $4000 \mathrm{BCE}$ & Drinking water dug wells across Mohen-jo Daro \\
\hline & & & $2200 \mathrm{BCE}$ & Sanitation facility across urban South ASia \\
\hline & & & $500 \mathrm{BCE}$ & Groundwater wells across universities and monasteries \\
\hline & & & $200 \mathrm{CE}$ & Kallanai Dam built across Cauveri river to store water \\
\hline & & & $1335 \mathrm{CE}$ & West Yamuna Canal constructed \\
\hline & & & $1500 \mathrm{~s} \mathrm{CE}$ & Sanitation structures and fountains in Mughal Era \\
\hline & & & 1600s CE & Inundation channels constructed by Mughals \\
\hline & & & 1700s CE & Extensive groundwater usage for domestic purpose \\
\hline & $1757 \mathrm{C}$ & \multirow{6}{*}{ Colonial } & $1800 \mathrm{~s}$ & $\sim 800,000$ hec of irrigated farmland in South Asia \\
\hline & \multirow[t]{5}{*}{ Eonwards } & & $1817-1923$ & $\begin{array}{l}\text { Six major sanitation-induced cholera and enteric disease epidemic in Ganges basin } \\
\text { cities, mostly Calcutta }\end{array}$ \\
\hline & & & 1863 & $\begin{array}{l}\text { Royal Commission of the British army in India recommends formation of Commission } \\
\text { of Public Health. Sanitary Commissioners and boards are appointed in each province } \\
\text { of British India }\end{array}$ \\
\hline & & & $1890 \mathrm{~s}$ & British India has largest irrigated farmland across world \\
\hline & & & 1917 & $\begin{array}{l}\text { Punjab Drainage Commission formed to look at soil salinization related to surface and } \\
\text { groundwater }\end{array}$ \\
\hline & & & $1940 \mathrm{~s}$ & 22 million hec of irrigated farmland in South Asia \\
\hline & \multirow[t]{11}{*}{$\begin{array}{l}1947 \mathrm{CE} \\
\text { onwards }\end{array}$} & \multirow{11}{*}{$\begin{array}{l}\text { Post-inde- } \\
\text { pendence to } \\
\text { present }\end{array}$} & $1950 \mathrm{~s}$ & Severe Soil salinization in Punjab and Sindh area \\
\hline & & & 1954 & $\begin{array}{l}\text { Government of India implements first river conservation program with sewage } \\
\text { treatment facilities }\end{array}$ \\
\hline & & & $1960 \mathrm{~s}$ & $\begin{array}{l}\text { Introduction of Green Revolution resulted drilling of tube wells and switch to } \\
\text { groundwater-based irrigation }\end{array}$ \\
\hline \multirow{13}{*}{$\begin{array}{l}\text { 1970s } \\
\text { onwards }\end{array}$} & & & 1965 & India imports high-yielding wheat seeds from Mexico \\
\hline & & & $1970 \mathrm{~s}$ & $\begin{array}{l}\text { Groundwater replaces surface water as major drinking water source. Major thrust on } \\
\text { enhanced use of fertilizer for crop production. Initiation of mechanized and electric- } \\
\text { operated extensive groundwater pumping }\end{array}$ \\
\hline & & & $1980 \mathrm{~s}$ & $\begin{array}{l}\text { Detection of arsenic and fluoride contamination in groundwater. Cropping pattern } \\
\text { switched to high-yielding water intensive crops }\end{array}$ \\
\hline & & & $1990 \mathrm{~s}$ & Change to water-intensive food pattern \\
\hline & & & 1992 & Solar-operated groundwater pumping programs starts \\
\hline & & & 2009 & Severe groundwater depletion noted by GRACE mission \\
\hline & & & 2015 & Groundwater base flow decrease starts Ganga drying \\
\hline & & & 2017 & $\sim 92$ million hec of irrigated farmland in South Asia \\
\hline & \multirow[t]{5}{*}{$\begin{array}{l}2020 \mathrm{CE} \\
\text { onwards }\end{array}$} & \multirow[t]{5}{*}{$\begin{array}{l}\text { Predicted } \\
\text { future }\end{array}$} & $\begin{array}{l}2020- \\
2100 \mathrm{~s}\end{array}$ & $\begin{array}{l}\text { Climate change influence hydrological cycle, there by influencing groundwater } \\
\text { recharge and discharge }\end{array}$ \\
\hline & & & 2025 & Severe groundwater based drinking water crisis \\
\hline & & & 2045 & Half of Indian population turns urban \\
\hline & & & 2050 & $\begin{array}{l}\text { Reduced groundwater base flow dries Ganga river in summer, severely affecting food } \\
\text { production }\end{array}$ \\
\hline & & & 2060 & Human population peaks and then gradually declines \\
\hline
\end{tabular}


back-yard, in comparison to distant-supplied surface water (Table 1).

\section{Availability and Quantifications}

Groundwater, as a natural resource, is sourced to porous or crystalline underground aquifers that are naturally recharged over time by precipitation e.g., rainwater infiltrating into the ground (Fig. 2, 3). Groundwater recharge is heavily dependent on the spatio-temporal pattern and volume of precipitation, and other land-based and hydrogeologic factors. Groundwater discharges by natural drainage or abstracted by human-sourced abstractions. When the rate of discharge exceeds the rate of recharge, the groundwater storage in the aquifers would dwindle, leading to decline of groundwater tables. Because of the geological evolution of the Indian continental landmass, there are two predominant groundwater systems that exist in the country: the prolific, Indus Ganges Brahmaputra (IGB) basin sourced porous fluvial aquifers, and the fractured, crystalline/hard rock aquifers of the Indian Craton (Mukherjee, 2018; Saha et al., 2019).

The porous aquifers of the country, predominated by the existence of IGB basin alluvial aquifers, are characterized by hundreds of meters of unconsolidated sediments that are weathered and rapidly deposited in the basins, thus forming some of the most prolific groundwater aquifers of the world. The IGB is regarded as the "bread-basket" of South Asia

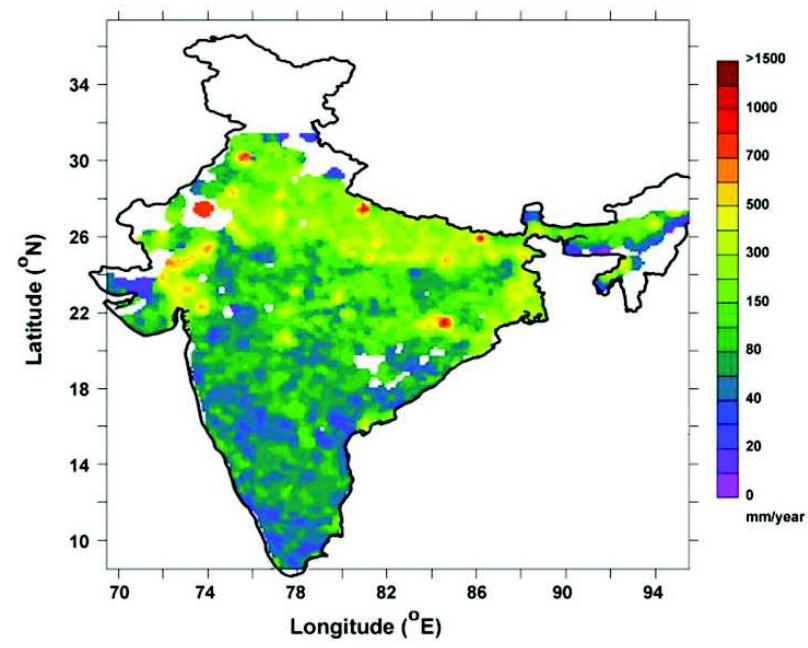

Fig. 2: Mean recharge (1996-2015) across India, calculated from in-situ measurements and tracer injection [redrawn from Bhanja et al. (2019)]. Areas with missing data are shown as white areas in the map
(Mukherjee et al., 2015; Mukherjee, 2018). The thick, unconsolidated alluvial aquifers are also very conducive to recharge. The coastal alluvial aquifers on the eastern coasts of India also host few prolific and replenishable aquifers. Over-abstraction in these regions leads to relatively slower decline of groundwater levels, albeit eventually necessitating exploration from deeper depths and increased abstraction rates (ITT, 2018). However, consequent to this water-richness, some of the most hard-hit areas that presently witness the most severe groundwater depletion include parts of this IGB basin (Bonsor et al., 2017; Saha et al., 2019).

Most of the cratonic, peninsular parts of India are characterized by the hard rock aquifers. The hard rock aquifers are typically characterized by limited quantities of groundwater storage in the weathered soil and sub-soil horizons of few to several meter thickness, underlain by the less-porous, un-weathered bedrock aquifers. The bedrocks are typically devoid of primary porosity, but are characterized by variable quantities of secondary porosity formed by fractures, cracks and fissures, where groundwater flows through preferential pathways (Saha et al., 2019). Groundwater in the hard rock aquifers are

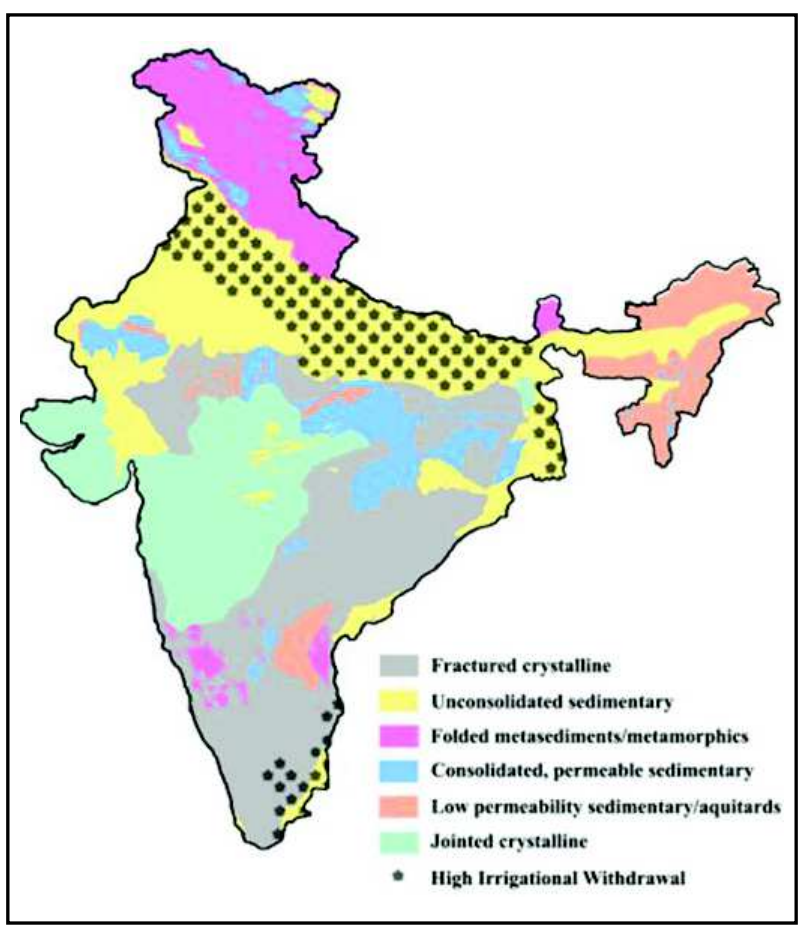

Fig. 3: Major aquifer types across India. Areas with intense groundwater irrigation are marked [input from Mukherjee et al. (2015) and Bhanja et al. (2017)] 
characterized by lower productivity of abstracting wells, less predictable spatio-temporal storage and productivity, and generally with deteriorated to poor groundwater quality. Thus, the groundwater resource availability in the hard rock regions is limited and discontinuous, which results to unreliable prediction and estimation of the groundwater availability for human usage. Unsustainable groundwater abstraction from these hard rock aquifers leads to rapidly declining groundwater levels, imposing severe limitations on groundwater extraction rates. Consequently, exponentially increasing groundwater demands in several parts of these hard rock regions of peninsular parts of India, are witnessing rapid groundwater storage dwindling, resulting in severe over-draft, where abstraction rates substantially exceeds recharge rates. As a result, over time there is a substantial increase in well drying.

Depending on the groundwater level decline rates and the aquifer productivity, groundwater overextractions can sustain for few decades. With advanced technologies, groundwater exploration and abstraction from deeper depths are plausible options (Mukherjee et al., 2015; Mukherjee, 2018). The need of additional energy for pump operations as well as
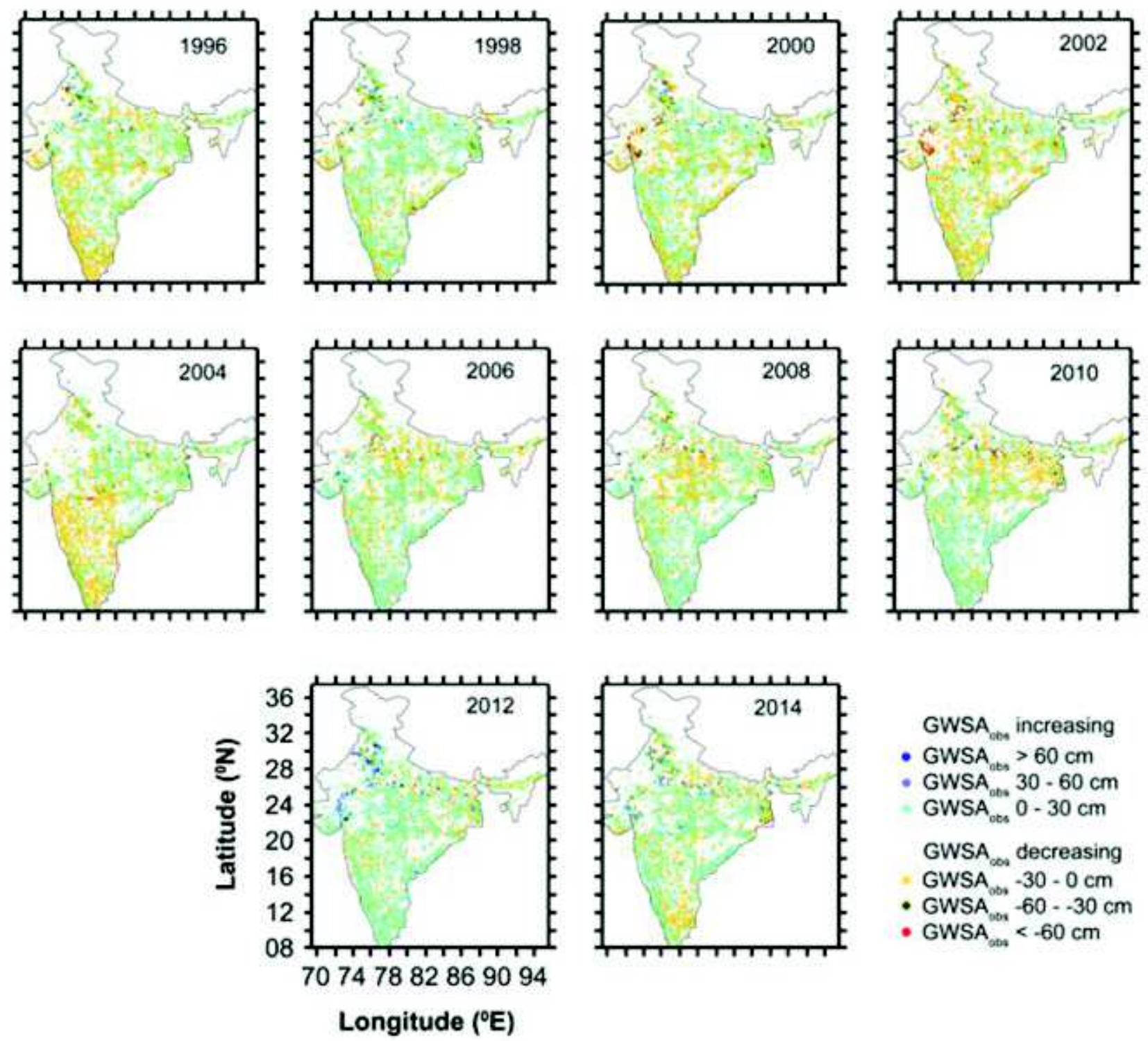

GWSA increasing

- GWSA $>60 \mathrm{~cm}$

- GWSA $30-60 \mathrm{~cm}$ GWSA $_{\text {obs }} 0-30 \mathrm{~cm}$ GWSA $_{\text {COS }}$ decreasing GWSA $-30-0 \mathrm{~cm}$

- GWSA $-60--30 \mathrm{~cm}$

- GWSA $\mathrm{Gba}^{<-60 \mathrm{~cm}}$

Fig. 4a: Evolving groundwater storage across India (1996-2014), estimated from in-situ measurements [redrawn from Bhanja et al. (2017) and Mukherjee (2018)] 


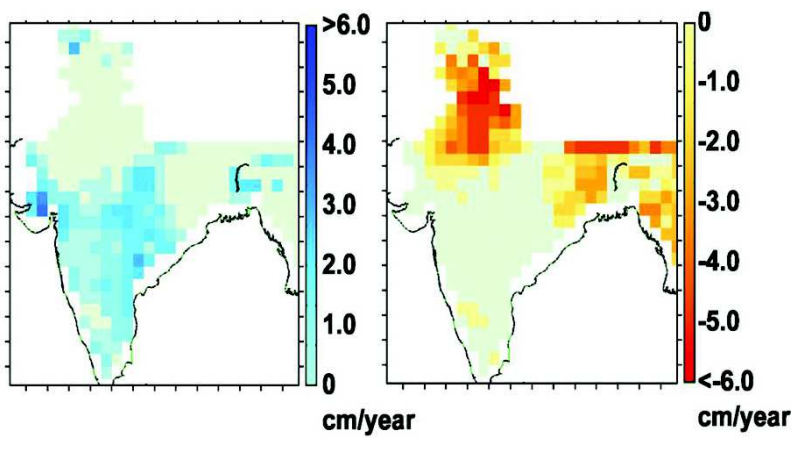

Fig. 4b: Satellite-based estimation of groundwater storage replenishment and depletion across India (20022014) [redrawn from Bhanja et al. (2017) and Mukherjee and Bhanja (2019)]

questions on deteriorating groundwater quality in context to drinking water standards are emerging as the burning issues. Hence, the future availability of the fresh water for the development of this country would be pivoted between un-judicious abstractions and governance options for reserving groundwater for present and impending needs, eventually leading to the water security for drinking water, food production and societal growth of future generations of Indians through the access of clean water (ITT, 2018).

\section{Changing Landscapes of Indian Groundwater}

Human civilization has been flourishing in the IGB basin from Paleolithic age, and at present, is regarded as one of the extremely densely populated part of the globe. The fluvial plain and deltas of the IGB basin are extremely fertile, and hence conducive for cultivation for food production. The rapidly increasing demands for irrigation water sourced to groundwater are directly proportional to the exponential increase in food demand for proliferating population (Mukherjee et al., 2015; Mukherjee, 2018). Consequently, everincreasing population, cultivation of water-intensive crops (e.g. high yield boro rice), cropping pattern changes (e.g. food crop replacement by cash crop) are some of the most acute causes for severe groundwater water storage (GWS) depletion. Much of the Indian states like Punjab (98\% percent of gross crop area is irrigated), Haryana (85\%), Uttar Pradesh (76\%), Bihar (61\%) and West Bengal (56\%) are located in the IGB aquifers and are undergoing severe groundwater storage depletion. Parts of the states of Punjab, Haryana, Rajasthan, Delhi and West Bengal have all recorded $>4 \mathrm{~m}$ groundwater decline during the last decade (CGWB, 2014a, ITT, 2018).

In situ and satellite-based groundwater resource trends and estimates show concomitant, synchronous, unequal changes of groundwater water storage (GWS) and level (GWL) between 1996 and 2014 across the country (Fig. 4a). While, parts of the IGB river basin aquifers mostly suggest declining groundwater storage, several parts of southern and western India show rejuvenating trends (Fig. 4b). The GWS changes, calculated as anomaly demonstrates strong spatio-temporal variability in the study region.

Following earlier observations of several workers for earlier periods, observed data shows that GWS (1996-2017) of eastern and northern zones are undergoing a rapid decline, at a rate of $3.59 \pm 0.14 \mathrm{~km} 3$ / year and $4.55 \pm 0.11 \mathrm{~km}^{3} /$ year, respectively. Similarly, satellite-based estimates (2002-2016) also indicate rapid depletion in eastern and northern zones at a rate of $-1.16 \pm 0.35$ and $-1.40 \pm 0.14$ and $\mathrm{cm} /$ year ($14.02 \pm 1.37$ and $14.49 \pm 4.36 \mathrm{~km}^{3} /$ year), respectively. These observations of rapid groundwater loss are in line with the previous estimates of northern India (54 $\mathrm{km} 3 /$ year, 2002-2008; Tiwari et al., 2009), northwest India (17.7 km3/year, 2002-2008; Rodell et al., 2009), and eastern parts of Indian subcontinent by Shamsuddhuha et al. (2012b). On the contrary, the observed GWS estimates suggest rejuvenation GWS in southern and western parts of the country at a rates of $0.31 \pm 0.02 \mathrm{~km}^{3} /$ year and $1.06 \pm 0.03 \mathrm{~km} 3 /$ year. Comparison of in-situ groundwater level fluctuation of decadal mean (2001 to 2010) to 2011 (CGWB, $2012 b$ ) by the Central Ground Water Board, Government of India, in general, suggests groundwater depletion in northwestern, northern, and eastern India, and replenishment in western and southern India across hydrological year. In more than half of the measured observation wells, there has been a decline of e" $1 \mathrm{~m}$ /year of groundwater level trends for premonsoon seasons from 2007 to 2012 (CGWB, 2014a).

\section{Groundwater Quality and Health}

Indiscriminate use of rivers and other surface-water bodies in these areas for disposal of sewage and industrial waste has rendered them non-potable. The use of these waters have resulted in recurrent epidemics of water-borne diseases in pre-and newlyIndependent India. Hence, since, 1970s, in many urban 
and rural areas of the country, inhabitants and policy implementing authorities are gradually switching over to groundwater sources to meet their drinking and domestic water needs (Mukherjee, 2018). Presently, $>70 \%$ of the domestic water supplies across the country is met by groundwater. However, there is a growing concern about the availability of safe water in many areas due to presence of natural contaminants (Mukherjee et al., 2015; Mukherjee, 2018) (Fig. 5).

Recent estimates show that about $1 / 4^{\text {th }}$ of the 300 billion $\mathrm{m}^{3}$ of IGB aquifer's groundwater are brackish and non-potable. Further $\sim 40 \%$ of groundwater is contaminated by naturally occurring, elevated concentrations of non-point sourced contaminants like As and F in groundwater, which have put $>100$ millions of people at public health risk (Mukherjee et al., 2015), thus making $\sim 60 \%$ of the groundwater in the IGB aquifers to be delineated as unusable and unsafe (MacDonald et al., 2016). The extent and effect of other emerging and unidentified groundwater contaminants (e.g. nitrate, pesticides, radiogens, antibiotics etc.) are yet to be accounted for. Intensive agriculture is associated with generous input of chemical and synthetic pesticides that infiltrates to groundwater systems (Saha and Alam,

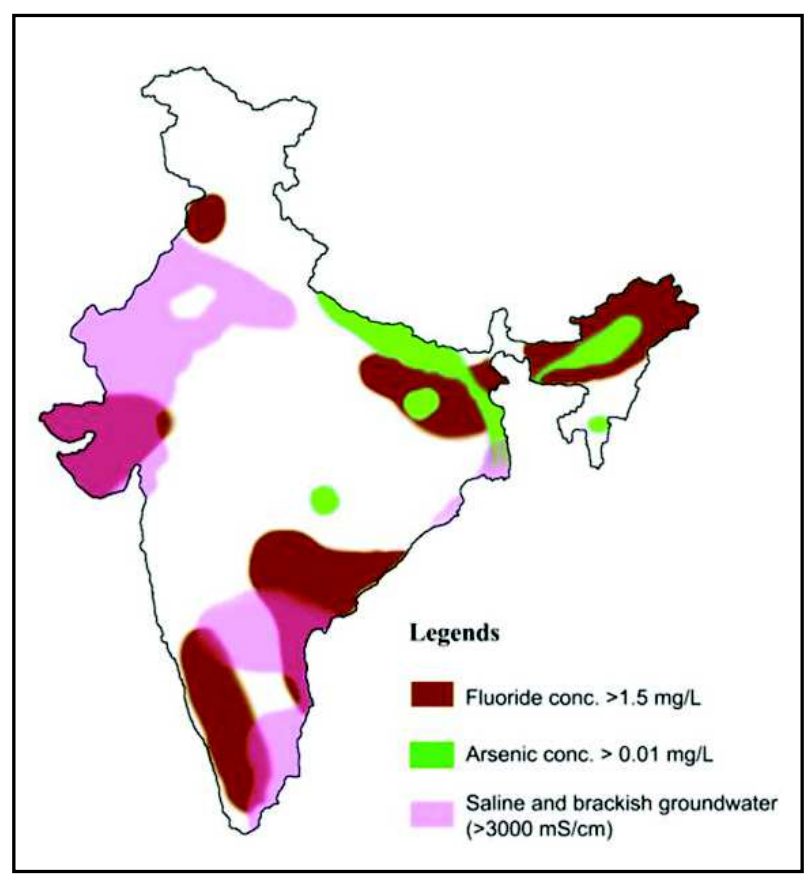

Fig. 5: Generalized map of non-point source, geogenic groundwater contamination across India [redrawn from Mukherjee et al. (2015) and Mukherjee (2018)]. Isolated hot-spots cannot be demonstrated at the scale of present map
2014). A more acute, but barely reported and discussed groundwater pollution can be linked to improper sanitation, which has resulted in a wide concern to public health.

\section{Natural Pollutants}

Elevated concentrations of naturally occurring, geogenic pollutants such as Arsenic and Flouride in groundwater are common in some regions of South Asia. These contaminants can be sourced back to geological formations of the aquifers, where As and $\mathrm{F}$ exist as trace elements in rocks. Arsenic contamination of groundwater, has exposed $>50$ million inhabitants just in the Bengal Basin resulting in 'the largest mass poisoning in human history' (Smith et al., 2000), and has been reported from 86 districts of 10 Indian states (Mukherjee et al., 2009b; Bhattacharya et al., 2014; CGWB, 2014; Mahanta et al., 2015; Verma et al., 2015 with a total of $>100$ millin people at risk drinking polluted groundwater (Mukherjee et al., 2020a). As-bearing aquifers are mostly reported from the Ganges-Brahmaputra river basin aquifers across the Indian states of West Bengal, Assam, Bihar and Uttar Pradesh and have been suggested to be linked to the sediments derived from the eastern Himalayas, specifically Siwaliks. In recent times, wide-spread pollution has also been suggested from the Indus basin of Punjab, but is yet to be confirmed. Groundwater of these IGB aquifers is anoxic, and conducive of redox-dominated metal cycling processes (Bhattacharya et al., 2011, 2014). The pollution may have also further aggravated due to extensive groundwater abstraction (Mukherjee et al., 2011). The 1980s-90s, saw the advent of chronic diseases related to As. The first As contaminated water-related health issues cases were observed in the early 1980s in Bangladesh and West Bengal, and first reported in the medical literature in 1984 (Garai et al. 1984). Prolonged exposure to water with elevated arsenic levels can result in serious health conditions, including skin lesions, hyperkeratosis, melanosis, and cancer in different organs, which in some cases can be fatal (Mukherjee et al., 2009).

While the health effects of consumption of Ascontaminated water is well understood, its impact through food chain, specifically through crops that are being irrigated with contaminated water, are still uncertain. The amount of As available for uptake by 
crops is influenced by multiple factors including soil redox potential, $\mathrm{pH}$, organic matter content, soil microbes, and the levels of iron, manganese, phosphorus and calcium carbonate in the soil. Moreover, arsenic that is taken up by plants tends to accumulate primarily in the plant roots, with progressively decreasing accumulation in stems, leaves and grains. Possibly the most important impact of irrigation with Arsenic contaminated water is the significant reduction in rice yields after prolonged use (Huhmann et al. 2017). Studies of correlation between Arsenic in irrigation water and Arsenic in rice grains so far have provided inconclusive and sometimes contradictory outcomes, and hence are a topic of active research (Chatterjee et al., 2010).

High concentrations of groundwater fluoride have also been observed, mostly in the crystalline aquifers in parts of 19 states (Maheshwari, 2006; CGWB, 2015; Hallet et al., 2015). It is reported that $>66$ million people in India are exposed to high concentrations of fluoride in groundwater (Mumtaz et al. 2017). The worst affected areas are the states of Rajasthan, Gujarat and Andhra Pradesh. Concentration of $0.8-1.0 \mathrm{mg} / \mathrm{L}$ is essential for calcification of dental enamel, however higher concentrations $(1.5-2 \mathrm{mg} / \mathrm{L})$ can lead to dental fluorosis (Sinha Roy, 2019). At still higher concentration, (3-6 mg F/L) skeletal fluorosis occurs, affecting bones and ligaments.

High concentrations of groundwater iron $(\mathrm{Fe})$ and nitrate $\left(\mathrm{NO}_{3}^{-}\right)$have also been reported from several aquifers of the country (CGWB, 2014b). Sea water intrusion resulting to aquifer salinization has also been observed in many of the aquifers adjoining the coastal regions of Bay of Bengal and Arabian Sea, however, highly saline groundwater are also prevalent in the inland aquifers of several states (CGWB, 2014a). Such inland salinization may be linked with mineral dissolution and/or agricultural pollution (MacDonald et al., 2016; Bonsor et al., 2017). Frequent, wide-spread floods, caused by intense precipitation and rejected recharge are common in parts of eastern India.

\section{Industrial Effluent and Agricultural Runoff}

Rapid industrial and agricultural expansions in India during recent decades have resulted in exposure to a diverse range of chemical contaminants that are increasingly polluting surface water and groundwater (ITT, 2018). Industrial pollution is generally increasing as the overall industrial productions in numerous diverse industrial facilities are growing faster than the adoption of best-practice cleaner industrial processes. Industrial effluent is typically concentrated through "point source" pollution from individual facilities (Mukherjee et al., 2011, 2018b), while agricultural runoff is diffuse non-point source pollution, originating from large areas. Processing of industrial chemicals to food production, generate a huge volume of industrial effluent pollutants that eventually can get transported to the groundwater systems, eventually ending up to the drinking water sources. These effluents contain a wide range of chemical and biological contaminants (e.g. Persistent Organic Pollutants [PoPs], Polycyclic Aromatic Hydrocarbons (PAH), Antibiotics) that are extremely toxic, ignitable, corrosive and reactive, which can cause severe human health effects. Further, two particularly concerning types of toxins discharged through industrial effluents to groundwater include heavy metals and endocrine disruptors (Mondal et al., 2012). Heavy metals such as lead, mercury, cadmium and chromium are very common contaminants in these effluents. These pollutants cannot be degraded or destroyed and also bio-accumulate in the body over time. Exposure to lead affects multiple body systems. Young children are particularly vulnerable to the toxic effects of lead which can interfere with the body's natural hormones and cause permanent brain and nervous system damage (Sorensen et al., 2016). Even at very low levels of exposure, they may cause reproductive and other health problems in humans and animals, including infertility and early puberty. Industrial sectors like distilleries, pesticides, textiles, pharmaceuticals, pulp and paper, tanneries, dyes, sugar mills, petrochemicals, electroplating, steel, food processing etc. all contribute to these pollutant pool in one way or other (ITT, 2018).

Agricultural practices that were initiated during the "Green Revolution" of 1960s-70s, involve use of large amounts of agrochemicals to improve crop production. They include fertilizers and pesticides and they discharge from excess-used crop lands, to infiltrate and pollute the groundwater (Saha and Alam, 2104). Nitrogen and phosphorus fertilizers result to their enhanced occurrence in groundwater, thereby modifying the chemistry and providing strong feedback effect through chemical modifications. Many 
agricultural pesticides, e.g. the PoPs, do not degrade readily and therefore persist in the groundwater for a prolonged period. They tend to bio-accumulate as well as get biomagnified in organisms drinking the polluted groundwater (ITT, 2018). Even at a low dose of exposure, these contaminants can cause human health effects like immune-suppression, diminished intelligence, hormonal imbalance, reproductive abnormalities and can eventually lead to cancer (Mondal et al., 2012).

\section{Sanitation Induced Pollution and Achieving UN Sustainable Development Goals}

It is well known that inadequate channelization of human excreta to nearby surface and groundwater due to improper sanitation infrastructure, are mostly observed among poverty-stricken populations, leading to severe public health hazard across the world. Thus, about $10 \%$ of the global human diseases comprise of improper sanitation-borne diseases, as more than 1 billion of the global poor still have to resort to open defecation due unavailability of suitable basic sanitation structures, making its alleviation as one of the prime goals of the United Nation's Millennium Development program (Duttagupta et al., 2019). India's societal economic growth has been extremely bipolar, which had historically been devoid of access to proper sanitation and safe drinking water sources. This led to an extremely vulnerable population that has suffered from recurring wide-spread epidemics related to water-borne pathogens. Six cholera pandemics have been recorded in the IGB area between 1817 and 1923 (ITT, 2018). During 1854 pandemic, cholera was identified to have occurred from use of unsafe water and lack of hygiene. The Imperial Government of the time initiated Royal Commissions, which was mandated to assess the sanitary conditions of India (Ramasubban 2008). In turn, the committee instituted the sanitary commissions in every province in India (ITT, 2018).

Even in $2500 \mathrm{BC}$, our ancestors in the ancient Indus Valley Civilization were aware of the benefits of water supply and sanitation facilities. The urban areas of this civilization included improved facilities of disposal of faecal waste and underground drainage system. However, dissolution of this civilization led to the end of urbanization and sophisticated water management and sanitation system and open defecation practice was again introduced (ITT, 2018). Thus, at present $>500$ million ( $40 \%$ ) Indians probably still resort to open defecation, making it more than half of the $\sim 1$ billion global populations that lack proper sanitation and practices defecation in open (Sorensen et al., 2016). Nevertheless, as India grows economically, in the last one decade, specifically in very recent times, there has been a very serious effort to eradicate open defecation, with an ambitious plan of providing access to proper house-hold sanitation for every resident, thereby reducing water-borne pathogens and thus improving public health.

In 2014, the Government of India started a widely publicized campaign, known as "Swachh Bharat Abhiyan", in order to make the country opendefecation free. This mission has targeted to install household toilet in each household by subsidizing the cost. Moreover, since dedicated sewerage systems are mostly not regularly available outside the major urban centers, development and use of in-situ, standalone pit latrines have been widely encouraged and practiced in major peri-urban and rural parts of the sub-continent (Duttagupta et al., 2019). But this initiated a debate on the caveats of using improperly constructed pit-latrines within residential areas as that may potentially lead to leakage, with possible shortcircuiting of human excreta directly to the groundwater that may eventually be abstracted by shallow wells in vicinity for domestic purposes. There has been only limited studies to investigate this relationship (e.g. Graham and Polizzotto, 2013) and they are not conclusive (e.g. Howard et al., 2003).

Notwithstanding these concerns, incidences of water-borne diseases like diarrhea have substantially decreased since 1990s. Percentages of under-five year children who are underdeveloped also have reduced. Total numbers of cases of diarrhoea in children under five year of age have decreased from 320 million to 280 million within 20 years (1990-2010) in India (UN, 2017). Recent studies (Duttagupta et al., 2019) have indicated that efforts for the last few years by Indian administrative policies have encouraged development of basic sanitation structures and this serves to promote the progress towards achieving UN Sustainable Development Goal 6. However, the efficiency of achieving these development goals, in alleviating the water quality and improving public health. Studies across the IGB basin 
suggest that long-term trends in groundwater microbial pollution (faecal coliform) have significantly declined thus alleviating water quality. Economic development patterns recorded in these areas suggested discernable inverse relationship with faecal coliform concentrations in groundwater of most areas, although areas with inferior water quality, improper human practices were found to outweigh economic development (Duttagupta et al., 2019).

\section{The Groundwater-Food-Energy Nexus}

Food production is heavily dependent on availability of fresh water resources, because irrigational water demands globally consume the primary share of the fresh water reserve, constituting a total consumption of about $90 \%$ of fresh groundwater in the last century. The cumulative stress on groundwater reserves in India due to its large population of about 1.3 billion (which is projected to grow by another 570 million in coming 50 years), coupled with seasonal variation in rainfall has consequently resulted in a critically vulnerable state to water and food security in the Indian subcontinent (Scanlon et al., 2010). There has been a steady increase in total irrigated area under groundwater-fed irrigation, from about $30 \%$ in 1960's to more than $60 \%$ i.e., $\sim 6 \times 10^{5} \mathrm{~km}^{2}(\sim 19 \%$ of the areal landmass of India) at present times, which is estimated to rise further in the coming years as the surface water reserves dwindle out due to rapid depletion of many glaciers (Scanlon et al., 2010; Mukherjee et al., 2018). The effects of climate change are predicted to further aggravate the situation, as the rising annual temperatures are predicted to undergo an increase of $3.3^{\circ} \mathrm{C}$ by the end of $21^{\text {st }}$ century with $10 \%$ inflation in irrigation water demand per ${ }^{\circ} \mathrm{C}$ (Scanlon et al., 2010). The climatic patterns are expected to significantly change, with the decline in winter precipitation coupled with intense summer rains, having fewer days of rainfall resulting in a water imbalance within the hydrologic cycle and a reduction in net recharge of groundwater. An estimated decline in gross per capita water availability from about $1,800 \mathrm{~m}^{3}$ per annum in 2001 to about $1,100 \mathrm{~m}^{3}$ per annum in 2050 (Gupta and Deshpande, 2004).

Groundwater abstraction technology is a vast academic topic and is crucial in present days for sustainable water abstraction. One of the main classifications of drilling and recovery technologies is dependent on depth of aquifer in different geological media, since water withdrawal below $10 \mathrm{~m}$ by a shallow jet pump becomes a challenge. Thus $\sim 10 \mathrm{~m}$ depth acts as a threshold for bore wells beyond which deep pumps needs to be installed, which can pull the water from a certain depth to the surface (ITT, 2018). The basic requirement for this pump to be working is a source of power which is equivalent to reciprocating metal rods in most hand pumps, rotating shafts in line shaft pumps and electrical current in submersible electric pumps (ITT, 2018).

In the household of rural areas manual hand pumped or externally powered pumps are very common. These technologies made advancement during the International Drinking Water Decade, 198190. Keeping in mind the ergonomics and maintenance capacity of users, a vast scale deployment of robust pumps like India Mark III and Afridev made a decadal breakthrough. Shallow pumps also became common for small scale irrigation and household purposes. Revolutionary innovations are difficult for marginal developments in manual pumping technologies but improving coverage, maintenance and repair of these pumps can be an exception. Hence, electricitypowered or diesel fuel based pumps are becoming increasingly common. These pump sets are commercially available across Indian markets and found to have $\sim 30 \%$ average efficiency. When compared to industrialized countries $(50 \%)$, these efficiency levels are quite less (ITT, 2018).

Solar powered pump sets, which use photovoltaic (PV) arrays to convert sunlight to electricity, are under advancement. In India, PV pumps are still not that common, but are rapidly catching up grounds. The first installation of 15,000 solar irrigation pumps in India has been mainly concentrated in the states of Punjab, Rajasthan and Haryana (KPMG 2014). This technology has sufficient potential to provide a long term renewable energy source for Indians. Solar pumping use all harvested power and minimizes the associated losses unlike in battery or fuel driven pumps, thus making it very efficient. Solar pumping if integrated into village-level solar-powered mini-grid systems, may bring development to the farmers (e.g. the high capital cost of PV system is spread across many users) as well as to the mini-grid utility (e.g. having flexible and reliable pumping loads). But on the contrary, such uninterrupted power source and 
supply can result to a catastrophic condition because of un-inhibited, enhanced groundwater abstraction (ITT, 2018).

\section{Implications of Urbanization}

Rapid urbanization is potentially instigating doubling of the urban population in India in the next 30 years. At present, the urban population in India is increasing by $\sim 10$ million people per year (ITT, 2018), which would cause an unsustainable situation, where facilities would only be available for $<50 \%$ of the migrating population. Of these, the groundwater availability for increasing water demands of the urban population is becoming an emerging concern. While, as per estimation, an average of $\sim 40$ liters of water is used in a rural household, the average per capita water use by urban population is $\sim 130$ liters. Most of this excess water is sourced from groundwater. Moreover, to cater such increasing urban populations, newer industries have developed in the peri-urban hinterlands. These industries largely thrive on exploitation of groundwater resources and in turn pollute them by unplanned and inefficient discharge of industrial effluents and wastes in the adjoining water bodies.

Further, the improvement of socio-economic conditions within the urban population, leading to upgraded standards of living, improved educational facilities and employment generation have also led to rapid transformation of food habits. Thus, more waterintense food (including meat and dairy products) are replacing the traditional, local hydro-climate supported agriculture-based food products. Consequently, the need for enhanced water supply is increasing (Bhanja and Mukherjee, 2019). Thereby, each liter of urban water is practically becoming more "valuable" than a liter of irrigation water, as urban water usage for a concentrated population is more time-sensitive because of drinking, cooking, cleaning and sanitation purposes (Mukherjee et al., 2015; Mukherjee, 2018). Hence, an adequate and reliable supply of water to cities remains essential for transforming modern civilization. Thus the rapidly rising urban water demand from the developing cities contributes to groundwater overexploitation and consequent groundwater storage depletion in and around almost all major Indian cities at present and has the potential to become one of the most acute urban crises in near future.

\section{Groundwater Trade and Hydro-Dconomics}

"Virtual water" describes the water used to produce a crop or an industrial product, which then virtually flows with the harvested crop or the product when it is transported elsewhere. Virtual water flow typically takes the form of market-based food and commodity trade, but also occurs in the form of humanitarian transfers. Between countries, import and export of virtual water represents a potential lever for enhancing future global food security, depending strongly on economic factors. Virtual water flows between countries whenever water-intensive commodities such as food, feed and fiber are traded internationally. Dependence on global food markets may prove risky, as many other rapidly growing nations also increasingly rely on the same markets. National food availability can increase without increasing national water stress by increasing imports or reducing exports of food products. At present, India is regarded as the most prominent water exporting country across the globe (Dalin et al., 2017). That is, Indian products (food or industrial) that are getting exported to other nations are also carrying the water footprint, mostly as groundwater, with them (ITT, 2018). Within India, however, virtual water flows from water-scarce regions to water-rich regions. Among Indian states, Punjab exports the most virtual water while Bihar imports the most virtual water. The virtual water exported from Indus river basin (e.g. Punjab, Rajasthan) is largely unsustainable groundwater, while Ganga river basin (e.g. Bihar, Uttar Pradesh) possesses abundant un-utilized groundwater resources. Water-intensive agricultural commodities are traded between Indian states and represent flows of virtual water from exporting states to importing states. Among Indian states, Punjab and Uttar Pradesh export the most virtual water, while Bihar and Kerala import most virtual water (Fig. 6).

Current water allocation methods encourage more groundwater abstraction through bore wells and electric pumping and continue to give vicious incentives to farmers to over-exploit groundwater. Using suitable water pricing structures and appropriate subsidies can act as a powerful personal and institutional incentive to adopt water-saving behaviors, processes and technologies (Mukherjee, 2018). Appropriate valuation of water resources may be the single most important broad strategy to achieve water 

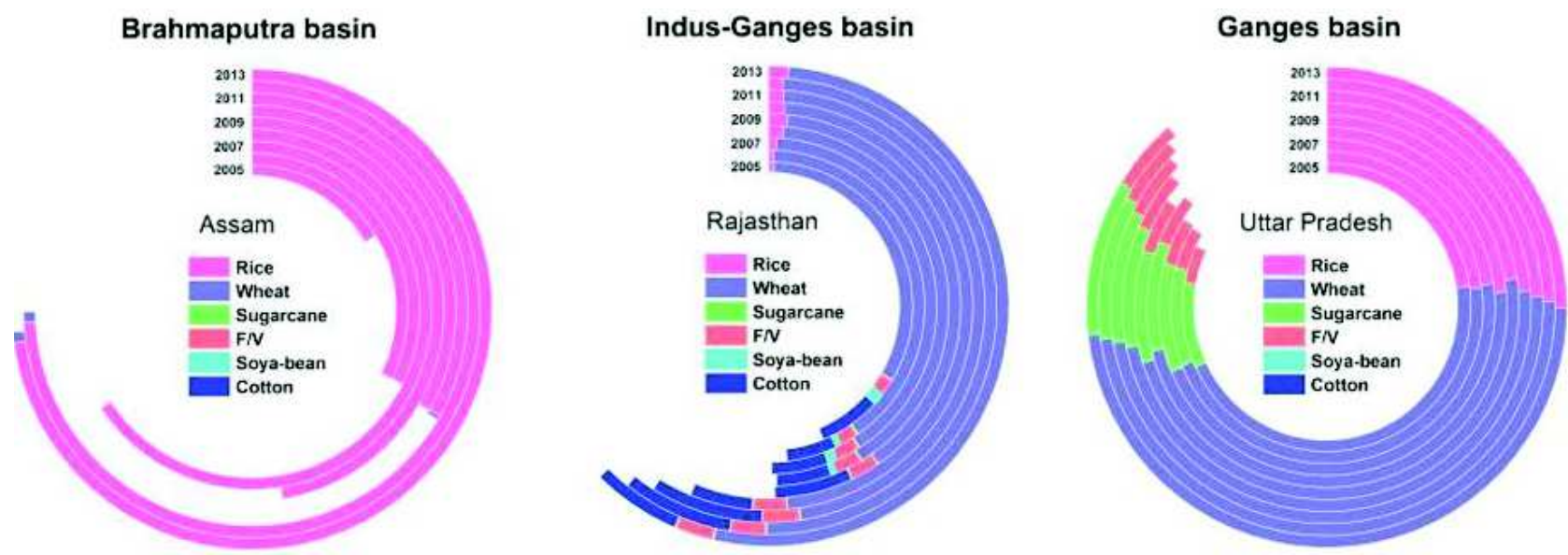

Fig. 6: Estimated proportions of groundwater-irrigated major food crops in the Indus, Ganges and Brahmaputra basins [redrawn from Bhanja and Mukherjee (2019)]

security. Realistic pricing would stimulate efforts to increase water efficiency and decrease waste, leading to improved water security. Out of reach pricing of basic quantities of water for the poorest populations, or failing to provide public stand-posts for free water, leads to urban economic water scarcity. Shifting societal consumption patterns toward foods with lower water use may be done using pricing, awareness raising, labeling or other incentives. Food pricing based on real societal costs of production would be beneficial, as water costs are generally not well reflected in the price of products due to subsidies in the water sector. Long-term water security benefits would primarily result from maintaining a waterefficient diet and avoiding the addition of more waterintensive foods to the diet (Mukherjee, 2018). Bringing water-intensive products from elsewhere avoids the need to use scarce local water for their production.

Transformational policies aiming for greater system integration are matching crop to location and water availability thus reducing food waste to reduce crop production requirements, which in turn is lowering the irrigational water demand. Due to various perverse incentives, water-intensive crops are increasingly grown in water-scarce regions of the country. Many agricultural development schemes have exclusively focused on crop productivity and economic goals, while ignoring mounting constraints and concerns about water availability. Two noteworthy examples include sugarcane production in the Indian state of Maharashtra, and rice production in Punjab state. Sugarcane is a water intensive crop, requiring a year- round water supply. In Maharashtra, despite $45 \%$ of the state being considered drought-prone, 26 out of 36 districts grow sugarcane (Bhanja and Mukherjee, 2019). Sugarcane cultivation has increased rapidly in Maharashtra during the past two decades and the state is now one of the leading sugar producers in India. Sugarcane cultivation utilizes $71 \%$ of all irrigation water in Maharashtra (ITT, 2018).

Prior to the Green Revolution, farmers in Indian Punjab grew a variety of crops, including wheat, pulses and coarse cereals. Since the 1960s, agriculture in Punjab has changed greatly and is now dominated by winter wheat and summer rice cultivations. This cropping pattern requires very large amounts of water, which in Punjab has been increasingly provided by groundwater. Currently, a non-trivial portion of the total food production is wasted, either on the farm, during transport and storage, or in the household. If that wastage could be reduced, fewer crops would need to be produced and thus, less water would be used. Jha et al. (2015) estimated that about 5 to 15 percent of most crops in India are lost during harvest or post-harvest. In general, dry crops such as cereals and pulses suffer less loss, while fresh crops such as fruits and vegetables have chances of greater levels of loss. Crop losses occur during harvest due to farmlevel technical and managerial issues and spoilages during processing and distribution which is largely a function of the available infrastructure. Anecdotal evidence suggests that losses at the household and consumer levels are minimal in India (ITT, 2018). Approaches to reducing food waste may involve 
technological innovation and efficient implementation, for example, refrigeration systems to reduce food spoilage at farms, distribution chains and households, which in turn would reduce water loss through footprints.

\section{Envisioning Groundwater Security}

The significance of ensuring groundwater security is no-where more evident than in South Asia, specifically India. Huge groundwater-dependent population, uncertain climate-reliant recharge processes, transboundary upstream water sources, major geogenic-sourced, non-point contaminants, archaic irrigation methods and human practices and indiscriminate land-use changes with urbanization, have rendered the Indian groundwater scenario to become a global paradigm for water scarcity, for both quantity and quality. Moreover, the changing climatic patterns in the recent times are expected to further exacerbate the groundwater stress (Mukherjee et al., 2015; Mukherjee, 2018).

With the turn of the century, India has become aspirant to become a 'developed' nation. A surging economy and a prolific young population have provided a unique opportunity to the country to take a global center stage (Mukherjee et al., 2015; Mukherjee, 2018). However, to achieve such a vision, it is crucial that inhabitants should get the basic social securities, including clean water, food and public health. Further, in a country that has a huge poor population it is imperative to assure the basic security of proper nourishment and access to clean water and sanitation, which should be the first priority of any administration. However, even after seventy years of the independence, this has been a long sought dream. More so, as groundwater, the primary source of fresh water in the country is rapidly declining, as well as water of several bigger rivers, including the Ganga, are dwindling.

In this backdrop, Right to Food Act (the National Food Security bill 2013) was proclaimed. However, it is realized that this bill wouldn't be sufficiently able to secure the food for the Indian citizens, as the agricultural productivity is intricately related to irrigation water supply, which is mostly sourced to groundwater. Further, availability of safe and sustainable drinking water is still unsecured. In this context, it is worthwhile to note that governments in recent years have discretely focused on better water management. One of the objectives for the sanitation structure development through the "Swatch Bharat Mission" may be perceived to be to supply potable, pathogen-free drinking water for everybody (Mukherjee et al., 2015; Mukherjee, 2018). The administrative declarations for setting up of enhanced groundwater management schemes, e.g., "Atal Bhujal Yojana" and irrigation schemes as "Pradhan Mantri Gram Sinchayee Yojana' with motto of 'har khet ko paani', thereby reducing the farmers' dependence on unpredictable rainfall for cultivation, can be pathfinders for basic improvement of the countries socio-economy (Mukherjee and Bhanja, 2019).

Thus, focusing on water security with the aim of preserving the existing water resources and working towards a functional resource efficiency and environmental management plan for sustainable use of groundwater resource (e.g., formulating a more efficient water management plan) is of utmost priority. Further, any interventions for future should be based on the ground-reality of aquifer hydrostratigraphy and lithology, as delineated by the National Aquifer Mapping Mission of the Government of India (Saha et al., 2019). Also, India shares several transboundary aquifers with its neighboring countries, planning and management of which is not only crucial for national security but also for domestic access to water. Waterborne diarrhea is reported to widespread and causes the largest number of deaths, resulting in more loss of human lives than by malaria, AIDS or TB (ITT, 2018; Mukherjee, 2018). In spite of the fact that UN Sustainable Development Goals for water has been recently achieved, billons of people in India, mainly from the poorest strata of society, are still deprived of safe water and proper sanitation. Several policy initiatives were undertaken by the earlier governments, such as 'Rajiv Gandhi National Drinking Water Mission' and "War for Water" by Department of Science and Technology (DST).

Public sector organizations such as the Department of Drinking Water, Government of India and Ministry of Water Resources, besides central and state water investigation directorates and public health departments established since 1951, have continuously worked towards developing successful national-level water and sanitation programs in pursuit of effective and judicial supply of water resources to every citizen 
of the country (Mukherjee, 2018). A national aquifer mapping program has also been initiated in recent times. However, despite the rigorous efforts, several parts of India still suffer from major water-related problems, e.g., the National Capital Region (NCR) of Delhi undergo severe water shortage in the summer months in recent years and regions of eastern India endure episodes of drought and flood, in each alternate years while, the legal conflict over sharing water reserves of Cauvery river watershed remains still unresolved even after a decade. The failure of much of the undertaken efforts from being successfully implemented, has been possibly caused by the gap in knowledge exchange/transfer between the different stakeholders, ranging from the researchers (evaluating the surface and subsurface water resources and formulating potentially successful water management plans) and the planners and decision-maker implementing those policies and programs from national to block levels to the end-user consumers. A successful nationally integrated water resource management and conservation program demands unification of all stakeholders in developing a holistic planning from its formulation to implementation and maintenance (Mukherjee, 2018).

\section{Potentials for Policy Interventions}

While, unregulated abstraction for enhanced irrigation of water-intensive cultivation (e.g. boro rice paddy, including Basmati) is resulting to one of the most rapid and drastic groundwater depletion in human history, recent paradigm shift in Indian central/state government policies on groundwater withdrawal and management strategies for sustainable water utilization are starting to demonstrate its results. In situ estimates show groundwater level replenishing trend in Andhra Pradesh, Maharashtra, Gujarat, Tamil Nadu, and Chattisgarh between 2005 and 2013 (CGWB, $2012 ; 2014 b$ ). In recent estimates, it has been found that several districts of western, central and southern India have been subjected to GWS replenishments. This phenomenon is probably caused by a combination of government policy changes and the grass root efforts of local communities, who have undertaken several projects over the last several years in the form of efficient ground water management and utilization policies (Shah, 2019). Potentially, such groundwater rejuvenation is linked with reduction in irrigation-linked groundwater withdrawal, change in agricultural practice, increasing artificial recharge, surface water irrigation increase, etc. (Bhanja et al., 2017 and references therein).

Policies like restriction of subsidized electricity for irrigation, separate electricity distribution for agricultural purpose (e.g. Jyotigram Yojana), construction of large-scale, regional enhanced recharge systems in waters-stressed crystalline aquifers (e.g. $\sim 700$ million USD costing Tapti river mega recharge project), artificial recharge of $85 \mathrm{BCM} /$ year in $\sim 0.5$ million $\mathrm{km}^{2}$ through $\sim 10$ million structures e.g. Pradhan Mantri Krishi Sinchayee Yojana), enhanced recharge by interlinking of river catchments (e.g. Narmada-Sabarmati interlinking), are hypothesized to have probably started replenishing the aquifers by increasing groundwater storage, as evident in GWL and GWS trends in parts of India (Mukherjee and Bhanja, 2019). Hence, the results of recent studies (Bhanja et al., 2017) illustrate a potentially optimistic scenario, where under conducive groundwater management policies, India can transform from "groundwater scarce" to "groundwater sufficient" (Mukherjee et al., 2020a).

\section{Conclusion}

For an aspiring country like India in pursuit of becoming a 'developed' nation, ensuring access to basic necessities like proper nourishment, safe drinking water and sanitation is fundamental to the country's economy. Being a groundwater-dependent nation in context to water availability and usage for domestic, industrial and agricultural purposes, securing groundwater for present and future is imperative to nation's sustenance and growth. However, groundwater resources in India are undergoing acute water scarcity issues, both in terms of available water quantity and safe water quality. The escalating population pressure coupled with heterogeneous distribution of groundwater resources, seasonal fluctuations in precipitation, unpredictable climatedependent recharge, transboundary water sources, archaic water intensive irrigational techniques, groundwater pollution by non-point geogenic contaminants and/or industrial effluents and sewage water, unplanned changes in land-use, random urbanization and the recent effects of climate change have all cumulatively contributed to the growing groundwater stress. Even though, housing some of the most prolific aquifer systems in the world, India 
still suffers 'groundwater droughts' in many areas, caused by the abstraction of 'largest groundwater volume in human history'. India is known to have the highest share of groundwater export, globally, through virtual water flows in international food trade. This excessive groundwater abstraction; mainly for food production has significantly impacted the socioeconomy by far.

Conducive, geogenic sources and processes result to pervasive, natural groundwater contamination (e.g. As, F etc.) across the country, posing severe health risk for millions of Indians. Additionally, indiscriminate introduction of human-sourced emerging pollutants to the groundwater and improper sanitation practices leads to further quality deterioration. Hence, scientifically-prudent, adaptive groundwater management strategies are immediately required to secure, sustain and rejuvenate the accessible, residual, unpolluted groundwater through times of changing socio-economic needs. However, recent studies do show scenarios of replenishment, potentially caused by policy interventions. Thus, proper, pervasive groundwater governance may optimistically lead to possibilities of transforming the country from a "groundwater-deficient" to "ground-water sufficient" nation and provide sustainable water availability for $\sim 1 / 5^{\text {th }}$ of the global population, in notso-far future.

\section{Acknowledgement}

The author is indebted to the knowledge acquired from

\section{References}

Bhanja S N and Mukherjee A (2019) In situ and satellite-based estimates of usable groundwater storage across India: implications for drinking water supply and food security Advances in Water Resources https://doi.org/10.1016/ j.advwatres.2019.02.001

Bhanja S N, Mukherjee A, Saha D, Velicogna I and Famiglietti (2016) Validation of GRACE based groundwater storage anomaly using in-situ groundwater level measurement in India Journal of Hydrology 543 729-738

Bhanja S N, Rodell M, Li B, Saha D and Mukherjee A (2017a) Spatio-temporal variability of groundwater storage in India Journal of Hydrology 544 428-437

Bhanja S N, Mukherjee A, Rodell M et al. (2017) Groundwater rejuvenation in parts of India influenced by water-policy his teachers, support of collaborators, and enrichment from his former and present students and postdoctoral scholars in visualizing the gamut of groundwater issues, specifically in context of India. Special acknowledgements are meant for Soumendra Nath Bhanja, Madhumita Chakraborty, Uttiya Dey, Srimanti Duttagupta, Prerona Das, Prangyaditya Malakar, Koshik Das, Animesh Bhattacharya, Sreedipta Chattopadhyay, and specifically, Poulomee Coomar at IIT Kharagpur, for help in preparation of this manuscript. Also, the author acknowledges the support of Alan Fryar (University of Kentucky), Bridget Scanlon (University of Texas at Austin), Prosun Bhattacharya (KTH, Sweden), Dipankar Saha (former CGWB), Matt Rodell (NASA), Yoshi Wada (IIASA), Kazi Matin Ahmed (Dhaka Univeristy), Debashish Chatterjee (Kalyani University), Roger Sathare (ITT), Ashok Ghosh (Bihar PCB), Ranjan Ray (CGWB), Martin Smith, Alan MacDonald and Dan Lapworth (British Geological Survey), Cliff Voss and John Lane (USGS), Tushar Shah (IWMI), Amar jeet Singh (former MoWR), Anwar Zahid (Bangladesh WDB), David Polya (Manchester University), Charles Harvey (MIT), Richard Taylor and Willam Burgess (UCL), Partha P. Chakraborty, Sudeshna Sarkar, Pabitra Mitra, Priyodarshi Pattanaik, Probal Sengupta and Sidhartha Chattopadhyay (IIT Kharagpur) for insights. The author also acknowledges the constructive review of the two anonymous reviewers and the efficient editorial Handling Editor, Prof. Ashok Singhvi and Prof. Deepak Srivastava.

change implementation, Sci Rep 7 7453. https://doi.org/ 10.1038/s41598-017-07058-2

Bhanja S N, Mukherjee A, Rangarajan R, Scanlon B R, Malakar P and Verma $S$ (2019) Long-term groundwater recharge rates across India by in situ measurements Hydrology and Earth System Sciences 23 711-722

Bhattacharya P, Mukherjee A and Mukherjee A B (2011) Arsenic contaminated groundwater of India. In Nriagu J (ed.): Encyclopedia of Environmental Health Elsevier B V (Netherlands), 150-164

Bhattacharya P, Mukherjee A and Mukherjee A B (2014) Groundwater Arsenic in India: Source, distribution, effects and alternate safe drinking water sources. Reference module in earth systems and environmental sciences, Chapter 09342. Elsevier B.V. (Netherlands). http://dx.doi.org/ 10.1016/B978-0-12-409548-9.09342-8, 19 p 
Bonsor H, et al., 2017. Hydrogeological typologies of the IndoGangetic basin alluvial aquifer Hydrogeology Journal doi:10.1007/s10040-017-1550-z

Central Ground Water Board (CGWB), 2012, G. o. I., Ministry of Water Resources. Ground Water Year Book - India 2011-12, p. 42pp

Central Ground Water Board (CGWB), 2014a, G. o. I., Ministry of Water Resources. Ground Water Year Book - India 2013-14, p. 76pp

Central Ground Water Board (CGWB), 2014b, G. o. I., Ministry of Water Resources. Dynamic Ground Water Resources of India, p. 283pp

Chatterjee D, Halder D, Majumder S, Biswas A, Nath B, Bhattacharya P, Bhowmick S, Mukherjee-Goswami A, Saha D, Hazra R and Maity P B (2010) Assessment of arsenic exposure from groundwater and rice in Bengal Delta Region, West Bengal, India Water Research 44 5803-5812

Dalin C, Wada Y, Kastner T and Puma M J (2017) Groundwater depletion embedded in international food trade Nature $\mathbf{5 4 3}$ 700

Dattagupta S, Bhattacharya A, Mukherjee A, Chattopadhyay S, Bhanja S N, Sarkar S, Malakar P and Bhattacharya J (2019) Groundwater faecal pollution observation in parts of IndoGanges- Brahmaputra river basin from in-situ measurements and satellite based observations Journal of Earth System Science $\mathbf{1 2 8}$

Deb Roy A and Shah T (2003) Socio-ecology of groundwater irrigation in India, in Intensive Use of Groundwater: Challenges and Opportunities, edited by R. Llamas and E. Custodio, pp. 307-335, Swets and Zetlinger, Lisse, Netherlands

Food and Agriculture Organization of the United Nations (FAO), 2013. FAO Statistical Yearbook 2013: World Food and Agriculture, $289 \mathrm{pp}$

Garai R, Chakraborty A K, Dey S B and Saha K C (1984) Chronic arsenic poisoning from tube-well water J Indian Med Assoc 82 32-35

Graham J P and Polizzotto M L (2013) Pit latrines and their impacts on groundwater quality: a systematic review Environ Health Perspect 121 521-530

Gupta S K and Deshpande R D (2004) Water for India in 2050: first-order assessment of available options Current Science 86 1216-1224

Hallet B, Dharmagunawardhane H A, Atal S, Valsami-Jones E, Ahmed S and Burgess W G (2015) Mineralogical sources of groundwater fluoride in Archaed bedrock/regolith aquifers: mass balances from southern India and northcentral Sri Lanka Journal of Hydrology: Regional Studies
$4111-130$

Howard G, Bartram J and Water S (2003) Domestic water quantity, service level and health. World Health Organization

Huhmann, Brittany L, Harvey C F, Uddin A, Choudhury I, Ahmed K M, Duxbury J B, Bostick B C and van Geen A (2017) Field study of rice yield diminished by soil arsenic in Bangladesh Environmental Science and Technology 51 11553-11560

Institute for Transformative Technologies (ITT), 2018. Technology breakthroughs for global water security: A deep dive into South Asia, 185 pp

Jha S N (2015) Report on Assessment of Quantitative Harvest and Post-Harvest Losses of Major Crops and Commodities in India. ICAR-All India Coordinated Research Project on Post-Harvest Technology, Ludhiana

Keynoyer J M (1998) Ancient cities of the Indus Valley Civilization. Oxford, $260 \mathrm{p}$

KPMG (2014) Feasibility Analysis for Solar Agricultural Water Pumps in India

Kumar R, Singh R D and Sharma K D (2005) Water resources of India Current Science 89 794-811

MacDonald A M, et al. (2016) Groundwater quality and depletion in the Indo-Gangetic Basin mapped from in situ observations Nature Geoscience 9 762-766

Mahanta C, Enmark G, Nordborg D, Sracek O, Nath B N, Nickson R T, Herbert R, Jacks G, Ramanathan A L, Mukherjee A and Bhattacharya P (2015) Understanding distribution, hydrogeochemistry and mobilization mechanism of arsenic in groundwater in a low-industrialized homogeneous part of Brahamputra river floodplain, India Journal of Hydrology: Regional Studies 4 154-171

Maheshwari R C (2006) Fluoride in drinking water and its removal Journal of Hazardous Materials 137 456-463

Mondal D, Ganguli B, Sen, Roy S, Halder B, Banerjee N, Banerjee M, Samanta M, Giri A and Polya D (2014) Diarrheal Health Risks Attributable to Water-Borne-Pathogens in ArsenicMitigated Drinking Water in West Bengal are Largely Independent of the Microbiological Quality of the Supplied Water Water 6 1100-1117

Mukherjee A (2018) Groundwater of South Asia. Springer Nature, ISBN 978-981-10-3888-4, Singapore

Mukherjee A, Fryar A E and O'Shea B M (2009b) Major occurrences of elevated arsenic in groundwater and other natural waters, in Henke K R, ed., Arsenic-Environmental Chemistry, Health Threats and Waste Treatment. Chichester, U.K., John Wiley \& Sons, p. 303-350 
Mukherjee A, Fryar A E, Scanlon B R, Bhattacharya P and Bhattacharya A (2011) Elevated arsenic in deeper groundwater of western Bengal basin, India: Extents and controls from regional to local-scale Appl Geochem 26 600-613

Mukherjee A, Saha D, Harvey C F, Taylor R G and Ahmed K M (2015) Groundwater systems of the Indian Sub-Continent Journal of Hydrology-Regional Studies 4A 1-14

Mukherjee A, Bhanja S N and Wada Y (2018a) Groundwater depletion causing reduction of baseflow triggering Ganges river summer drying Scientific reports 812049

Mukherjee A, Fryar A E, Eastridge E M, Nally R S, Chakraborty $\mathrm{M}$ and Scanlon B R (2018b) Controls on high and low groundwater arsenic on the opposite banks of the lower reaches of River Ganges, Bengal basin, India Science of the Total Environment 645 1371-1387

Mukherjee A and Bhanja S N (2019) An Untold Story of Groundwater Replenishment in India: Impact of LongTerm Policy Interventions. In Water Governance: Challenges and Prospects. Springer, Singapore, pp. $205-$ 218

Mukherjee A, Sarkar S, Chakraborty M, Duttagupta S, Bhattacharya A, Saha D, Bhattacharya P, Mitra A and Gupta S (2020a) Occurrence, predictors and hazards of elevated groundwater arsenic across India through field observations and regional-scale AI-based modelling. The Science of the Total Environment, pp. 143511-143511

Mukherjee A, Babu S S and Ghosh S (2020b) Thinking about water and air to attain Sustainable Development Goals during times of Covid-19 Pandemic Journal of Earth System Science 129 1-8

Mumtaz N, Pandey G and Labhasetwar P K (2015) Global fluoride occurrence, available technologies for fluoride removal, and electrolytic defluoridation: A review Critical Reviews in Environmental Science \& Technology $452357-$ 2389

Ramasubban R (2008) History of public health in modern India 1857-2005. Chapter 5 in: Lewis \& MacPherson. Public Health in Asia and the Pacific: Historical and Comparative Perspectives

Rodell M, I Velicogna and J S Famiglietti (2009) Satellite-based estimates of groundwater depletion in India Nature 460 999-1002

Saha D and Alam F (2014) Groundwater vulnerability assessment using DRASTIC and Pesticide DRASTIC models in intense agriculture area of the Gangetic plains, India Environ Monit Assess 186 8741-8763
Saha D, Marwaha S and Dwivedi S N (2019) National Aquifer Mapping and Management Programme: A Step Towards Water Security in India. In Water Governance: Challenges and Prospects Springer, Singapore, pp. 49-66

Saha D, Marwaha S and Dwivedi S N (2019) National Aquifer Mapping and Management Programme: A Step Towards Water Security in India. In: Singh A, Saha D and Tyagi A (eds) Water Governance: Challenges and Prospects. Springer Water. Springer, Singapore

Scanlon B R, Mukherjee A, Gates J B, Reedy R C and Sinha A N (2010) Groundwater recharge in natural dune systems and agricultural ecosystems in the Thar Desert region, Rajasthan, India Hydrogeology Journal 18 959-972

Sinha Ray S P and Elango L (2019) Deterioration of Groundwater Quality: Implications and Management. In: Singh A, Saha $\mathrm{D}$ and Tyagi A (eds) Water Governance: Challenges and Prospects. Springer Water. Springer, Singapore

Shah M (2019) Crafting a Paradigm Shift in Water. In: Singh A, Saha D and Tyagi A (eds) Water Governance: Challenges and Prospects. Springer Water. Springer, Singapore

Shamsudduha M, Taylor R G and Longuevergne L (2012) Monitoring groundwater storage changes in the highly seasonal humid tropics: Validation of GRACE measurements in the Bengal Basin Water Resour Res 48 W02508, doi: 10.1029/2011WR010993

Smith A H, Lingas E O and Rahman M (2000) Contamination of drinking-water by arsenic in Bangladesh: a public health emergency Bulletin of World Health Organization 78 10931103

Sorensen J, Sadhu A, Sampath G, Sugden S, Gupta S D, Lapworth D, Marchant B and Pedley S (2016) Are sanitation interventions a threat to drinking water supplies in rural India? An application of tryptophan-like fluorescence Water Res 88 923-932

Tiwari V M, Wahr J and Swenson S (2009) Dwindling groundwater resources in northern India, from satellite gravity observations Geophys Res Lett 36 L18401

UN (2017) Report of the Secretary-General, "Progress towards the Sustainable Development Goals" E/2017/66(2017)

Verma S and Phansalkar S J (2007) India's water future 2050: Potential deviations from 'business-as-usual' Intl Jour Rural Management 3 149-179

Verma S, Mukherjee A, Chaudhury R and Mahanta C (2015) Brahmaputra river basin groundwater: solute distribution, chemical evolution and arsenic occurrences in different geomorphic settings Journal of Hydrology: Regional Studies 4 131-153. 